\title{
Industrial Applications of Endoglucanase Obtained from Novel and Native Trichoderma atroviride
}

\author{
S. Sahin, ${ }^{a}$ I. Ozmen, ${ }^{\text {a, }}$ and H. Bıyık ${ }^{\mathrm{b}}$ \\ ${ }^{a}$ Suleyman Demirel University, Arts and Science Faculty, \\ Department of Chemistry, 32260, Cunur, Isparta, Turkey \\ ${ }^{b}$ Biology Department, Faculty of Art and Science, \\ Adnan Menderes University, Aydın, Turkey
}

doi: 10.15255/CABEQ.2014.2130

Original scientific paper Received: October 14, 2014 Accepted: June 6, 2016

An endo- $\beta$-1,4-glucanase (EG), produced under submerged fermentation by local isolate Trichoderma atroviride, was purified using ammonium sulfate precipitation, column and ion exchange chromatography with 55.16 fold and a specific activity of 30.9 EU mg ${ }^{-1}$. The studies of PAGE, SDS-PAGE and zymogram test have been carried out. The EG had optimum activity at $\mathrm{pH} 5.0$ and $50^{\circ} \mathrm{C}$ respectively. Using $\mathrm{CMC}$ as substrate, the enzyme showed maximum activity $\left(V_{\max }\right)$ of $6.7\left(\mu \mathrm{mol}\right.$ glucose $\left.\mathrm{min}^{-1}\right) \mathrm{mL}^{-1}$ with its corresponding $K_{\mathrm{m}}$ (Michaelis-Menten constant) value of $1.12 \mathrm{mg} \mathrm{mL}^{-1}$. While the EG activity was activated by $\mathrm{NaCl}$, inhibited by $\mathrm{MgCl}_{2}$ and $\mathrm{MgSO}_{4}$. Otherwise, Tween 80 , Triton X-100 and the total saponins known as biosurfactants enhanced the EG activity. The obtained EG had low $K_{\mathrm{m}}$ and high thermal stability. Additionally, usability of the EG in biotechnological application was investigated. The results showed that the EG had potentially sufficient effects on denim fabric and pretreated lignocellulosic wastes.

Key words:

endo- $\beta-1,4$-glucanase, purification, characterization, biosurfactant, saponin,

Trichoderma atroviride

\section{Introduction}

Lignocellulosic materials are cheap and the most abundant material on Earth. Especially, agricultural wastes (e.g. wheat straw and corn stover), forestry residues (e.g. mill wastes and sawdust), portions of municipal solid waste, and most industrial wastes are their source. ${ }^{1}$

Bioconversion of cellulose to soluble sugar is performed by cellulases. ${ }^{2}$ For effective degradation of cellulose, a complete enzyme system is necessary, which comprises three classes of enzymes; endo- $\beta$-1,4-glucanase (CMCase, EC 3.2.1.4, EG; randomly cleaving $\beta$-linked bonds within the cellulose molecule), cellobiohydrolases (EC 3.2.1.91, $\mathrm{CBH}$; removing cellobiose units from nonreducing ends of the cellulose chain) and $\beta$-glucosidase (cellobiase, EC 3.2.1.21, hydrolyzing cellobiose and cellooligosaccharides to glucose). ${ }^{3,4,5}$ These cellulases can be produced by most microorganism, including fungi, bacteria, and actinomycetes. Trichoderma and Aspergillus species are the most studied cellulolytic microorganisms for cellulase production. ${ }^{6}$

Lignocellulosic materials mainly consist of cellulose, hemicelluloses, and lignin. Cellulose is the main component of lignocellulosic materials, but there are two major obstacles for hydrolysis of cel-

"Corresponding author. Tel: +90-246-211 4111; Fax: +90-246-237

1106; E-mail: ismailozmen@sdu.edu.tr (Ismail Ozmen) lulose in lignocellulosic material. These are the recalcitrance of crystalline cellulose itself, and the highly protective lignin surrounding it. These problems can be eliminated using pretreatment method. Pretreatment methods provide increasing cellulose accessibility for enzymatic hydrolysis. ${ }^{7,8}$

Cellulases are the most important enzymes used in various industrial applications, such as food, textiles and laundry, pulp and paper, and agricultural, bioethanol production from lignocellulosic waste, extraction of fruit and vegetable juices, alongside research purposes. ${ }^{9}$ For this reason, there is an increasing demand for obtaining new, more specific, stable enzymes and the screening and characterization of novel isolates. ${ }^{10,11}$

Denim is remarkably popular in the textile industry. To create diversity in denim fabric, it is necessary to find new convenient applications to respond the huge market demand. Biostoning is the most successful textile application of cellulases. This application is used in denim finishing, creating the old-look and worn look in denim garments. The old look appearance in denim garments using cellulases results from non-homogeneous removal of indigo dye trapped inside the fibers. Cellulase treatment of denim fabric is an environment-friendly method compared to with stone washing. ${ }^{12,13}$

Otherwise, cellulases are utilized to improve the appearance of cellulosic garments by removing fuzz 
fibers and pills from the surface. Because the amorphous region of cellulose causes fuzz and pill formation on the garment surface, using a single type cellulase, preferentially endoglucanase, will be sufficient for removing fuzz and pill of amorphous cellulose. ${ }^{13}$

The purpose of this study was to determine some properties (optimum $\mathrm{pH}$, temperature, thermal stability, and kinetic properties) of EG from a local isolate Trichoderma atroviride. Otherwise, the paper presents the effect of EG on the properties of pretreated lignocellulosic wastes and denim fabric.

\section{Materials and methods}

\section{Chemicals}

Carboxymethylcellulose sodium salt (CMC-Na), 3,5-dinitrosalicylic acid (DNS) was obtained from Alfa Aesar (USA), Sephadex G-100, DEAE- Sephadex was obtained from Sigma Chemicals Co. Ltd (USA). Other chemical reagents were analytical grade.

\section{Microorganism and plants}

The microorganism used as EG producer was isolated from the shore of hot spring water, Karahayıt, Denizli. In this study, DNA isolation was performed using the classical phenol-chloroform method. Purity and concentration measurements were determined using the nanodrop spectrophotometer (Thermo). The polymerase chain reaction (PCR) was carried out at $95^{\circ} \mathrm{C}$ for 5 minutes, 35 cycles of 1 minute at $94{ }^{\circ} \mathrm{C}, 1$ minute at $55^{\circ} \mathrm{C}, 1$ minute at 72 ${ }^{\circ} \mathrm{C}$, plus an additional 7 minute cycle at $72{ }^{\circ} \mathrm{C}$. Internal transcribed spacer (ITS) primers were used in the reactions (ITS1 and ITS4). Electrophoresis was conducted in agarose gel (1.2\%). For sequencing, the sample was sent to Macrogen Europe. Sequence data was processed with Blastn. Sequence alignment was performed by using MEGA 6.06 software. The strain used in this study was a member of the genus Trichoderma, and identified as Trichoderma atroviride.

The Gypsophila arrostii Guss. var. nebulosa (Boiss. \& Heldr.), Gypsophila pilulifera Boiss. \& Heldr. and Ankyropetalum reuteri Fenzl. Boiss. were collected from Isparta, Antalya and Adiyaman Provinces of Turkey, respectively, and identified by the Department of Biology, Suleyman Demirel University.

The roots of the plants were dried to constant weight and then pulverized. Initially, the dried root powder for each plant $(100 \mathrm{~g})$ was extracted by stirring the suspension in petroleum ether as an apolar solvent at room temperature. Secondly, the saponins from the plant powder were extracted eight times with $70 \%$ aqueous ethanol solution. The solvent was evaporated at $100 \mathrm{mbar}, 80^{\circ} \mathrm{C}$, and the extract solution was then concentrated to remove the solvent under vacuum. After drying, total saponins for the Gypsophila arrostii (Total saponin I), Gypsophila pilulifera (Total saponin II) and Ankyropetalum reuteri (Total saponin III) (18 g, $13.5 \mathrm{~g}$ and $16 \mathrm{~g}$, respectively) were obtained.

\section{Cultivation of $T$. atroviride}

T. atroviride was cultured in a medium as described previously. ${ }^{14} 1 \%(\mathrm{w} / \mathrm{v}) \mathrm{CMC}$ was used as carbon source. Initial $\mathrm{pH}$ of the medium was adjusted at 5.0 with $\mathrm{HCl}$ and the medium was sterilized by autoclaving at $121^{\circ} \mathrm{C}$ for 15 minutes. After the culture medium was inoculated with $T$. atroviride, it was incubated at $35{ }^{\circ} \mathrm{C}$ with rotary shaking at 120 $\mathrm{rpm}$. The EG activity was measured for 6 days. A sample was withdrawn in medium every $24 \mathrm{~h}$ and centrifuged at $8.000 \mathrm{rpm}$ for 30 minutes. The EG activity of supernatant was determined.

\section{Endo- $\beta$-1,4-glucanase activity assay}

The endo- $\beta-1,4$-glucanase activity was determined based on the Ghose method ${ }^{15}$, and reducing sugars were measured using the 3,5 Dinitrosalicylic acid (DNS) method. ${ }^{16}$ The amount of reducing sugars liberated from $\mathrm{CMC}$ solubilized in $50 \mathrm{mM}$ Na-citrate buffer ( $\mathrm{pH}$ 5.0) by the enzyme was determined in this assay. The reaction was performed at $50{ }^{\circ} \mathrm{C}, \mathrm{pH} 5.0$ for 30 minutes. One unit of endo- $\beta$ 1,4 -glucanase activity was defined as the amount of enzyme that could hydrolyze CMC and release 1 $\mu \mathrm{mol}$ of glucose within 1 minute of reaction. The optical absorbance was measured at $540 \mathrm{~nm} \cdot{ }^{15}$ The cellulase activity was determined by using a calibration curve for glucose.

\section{Purification of EG}

After five days of cultivation at $35{ }^{\circ} \mathrm{C}$ with shaking (120 rpm), the culture medium was centrifuged at $8.000 \mathrm{rpm}$ for 30 minutes and the supernatant was used for purification of EG as the crude enzyme solution. All procedures were carried out at $25{ }^{\circ} \mathrm{C}$.

Solid ammonium sulfate was added to the supernatant at $60-80 \%$ saturation, and precipitated proteins were collected by centrifugation $(8.000$ $\mathrm{rpm}, 30$ minutes). The proteins were redissolved in a small amount of $50 \mathrm{mM}$ Na-citrate buffer ( $\mathrm{pH} 5.0)$ and then dialyzed against the same buffer. The dialyzed EG solution was then applied onto a pre-equilibrated Sephadex G-100 column $(1 \times 30 \mathrm{~cm})$ and elution was performed with $50 \mathrm{mM} \mathrm{Na-citrate} \mathrm{buffer}$ (pH 5.0) at $1 \mathrm{~mL} \mathrm{~min}{ }^{-1}$. Fractions containing EG activity were pooled and loaded onto DEAE Sepha- 
dex column $(1 \times 10 \mathrm{~cm})$. Elution was carried out with $50 \mathrm{mM}$ Na-citrate buffer ( $\mathrm{pH}$ 5.0) containing a linear gradient of $\mathrm{NaCl}$ from $0-0.5 \mathrm{M}$ at $1 \mathrm{~mL} \mathrm{~min}^{-1}$. The active fractions were pooled and then dialyzed against $50 \mathrm{mM}$ Na-citrate buffer ( $\mathrm{pH}$ 5.0). The obtained preparation was concentrated with lyophilization, and then used for kinetic studies and applied to SDS polyacrylamide gel electrophoresis (SDSPAGE) and native polyacrylamide gel.

\section{Native polyacrylamide gel electrophoresis (Native-PAGE) and zymogram test}

A $10 \%$ native PAGE separation gel containing $0.2 \%(\mathrm{w} / \mathrm{v}) \mathrm{CMC}$ was prepared for the zymogram test. Electrophoresis was performed at room temperature for $2.5 \mathrm{~h}$ at $150 \mathrm{~V}$ using Scie Plas TV100 Twin-Plate $(10 \times 10 \mathrm{~cm})$. After native PAGE, the gel was cut into two pieces for EG activity staining. One of the pieces was stained using the silver staining method. After other piece of the gel was incubated in Na-citrate buffer $(\mathrm{pH} 5.0)$ at $50{ }^{\circ} \mathrm{C}$ for 30 minutes, stained for 10 minutes with $0.1 \%$ Congo red, and then washed with $1 \mathrm{M} \mathrm{NaCl}$, until the enzyme bands had become visible.

\section{Sodium dodecyl sulfate-polyacrylamide gel electrophoresis (SDS-PAGE)}

This study was performed according to the method of Laemmli (1970). ${ }^{17}$ An equal volume of sample buffer $(10 \%$ glycerol, $5 \% \beta$-mercaptoethanol, $2 \%$ SDS, and $0.05 \%$ bromophenol blue in $0.25 \mathrm{M}$ Tris- $\mathrm{HCl}$ buffer; $\mathrm{pH}$ 6.8) was added to the purified enzyme and incubated in boiling water for 2 minutes. The samples were then subjected to SDS-PAGE (resolving gel and stacking gel, $10 \%$ and $5 \%$, respectively) using Scie Plas TV100 TwinPlate $(10 \times 10 \mathrm{~cm})$. Electrophoresis was performed at room temperature for $2 \mathrm{~h}$ at $150 \mathrm{~V}$. After electrophoresis, the gel was stained with Coomassie Brilliant Blue R-250. Thermo Scientific PageRuler ${ }^{\mathrm{TM}}$ plus prestained protein ladder was used as standard marker.

\section{Determination of the protein concentration}

Protein concentration was determined using the Lowry method. ${ }^{18}$ Bovine serum albumin (BSA) was used as standard protein.

\section{Optimum pH and temperature}

The optimum $\mathrm{pH}$ for endo- $\beta$-1,4-glucanase activity was determined using different $\mathrm{pH}$ buffers: 50 $\mathrm{mM}$ Na-citrate buffers ( $\mathrm{pH} 4.0-5.0$ ), and potassium phosphate buffers ( $\mathrm{pH}$ 6.0-9.0). The optimum temperature for endo- $\beta$-1,4-glucanase activity was determined under standard assay conditions at temperatures from $30{ }^{\circ} \mathrm{C}$ to $70{ }^{\circ} \mathrm{C}$.

\section{Thermal stability}

Thermal stability studies were carried out by incubating the enzyme at $50{ }^{\circ} \mathrm{C}$ for various durations (between 30 minutes $-72 \mathrm{~h}$ ). The amount of released reducing sugars was then determined by the DNS method.

\section{Determination of kinetic parameters}

For determining Michaelis-Menten constant $\left(K_{\mathrm{m}}\right)$ and maximal velocity $\left(V_{\max }\right)$ of the purified enzyme, the enzyme activity was detected using different concentrations of CMC $\left(0.7-2.63 \mathrm{mg} \mathrm{mL}^{-1}\right)$ in $50 \mathrm{mM} \mathrm{Na}$-citrate buffer $(\mathrm{pH} 5.0)$. The $K_{\mathrm{m}}$ and $V_{\max }$ were calculated from Lineweaver Burk plot.

\section{Substrate specificity}

Hydrolytic activity of purified EG toward $1 \%$ (w/v) Avicel, cellulose, cellobiose, CMC, filter paper, and wheat bran (WB) in $50 \mathrm{mM} \mathrm{Na}$-citrate buffer ( $\mathrm{pH}$ 5.0) was determined to evaluate the substrate specificity. The enzyme activity based on the amount of released reducing sugars was determined by the DNS method.

\section{Effect of some metal ions on the enzyme activity}

The effects of metal ions on the EG were determined by adding different concentrations of $\mathrm{NaCl}$,

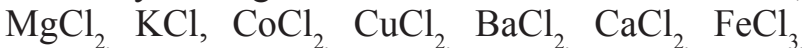
$\mathrm{MnSO}_{4}, \mathrm{FeSO}_{4}, \mathrm{CuSO}_{4}$, and $\mathrm{MgSO}_{4}$ to the activity assay medium.

\section{Effects of surfactants and biosurfactants on the enzyme activity}

The effect of surfactants and biosurfactants on the EG was determined by adding different concentrations of Triton X-100, Tween 80, total saponins to the activity assay medium. The effect of Tween 80 and Triton X-100 on EG was studied between $0.01 \mathrm{w} / \mathrm{v}-0.04 \mathrm{w} / \mathrm{v}$ and $0.0018 \mathrm{w} / \mathrm{v}-0.04 \mathrm{w} / \mathrm{v}$, respectively. Concentration of Gypsophila arrostii (Total saponin I), Gypsophila pilulifera (Total saponin II) and Ankyropetalum reuteri (Total saponin III) were $0.02-0.09,0.01-0.09,0.02-0.07 \mathrm{mg} \mathrm{mL}^{-1}$, respectively.

\section{Effect of the EG on the pretreated lignocellulosic waste}

Sawdust of calabrian pine, abies pine, poplar and WB were provided by Faculty of Forestry, Suleyman Demirel University.

Pretreatment of sawdust and WB was performed using 0.5 and $1 \mathrm{M}$ of $\mathrm{NaOH}$ and 0.05 and $0.1 \mathrm{M} \mathrm{H}_{2} \mathrm{SO}_{4}$. In $1 \mathrm{~L}$ of these solutions, $100 \mathrm{~g}$ of waste was mixed and incubated at $1 \mathrm{~h}$ at $72{ }^{\circ} \mathrm{C} .{ }^{19}$ 
The waste was then filtered, washed using tap water and distilled water until neutralization ( $\mathrm{pH} 7.0)$, and dried in a drying oven at room temperature. Additionally, the pretreatment without chemical addition was carried out with distilled water and used as control.

Enzymatic hydrolysis was carried out in a tube, with $2 \% \mathrm{w} / \mathrm{v}$ concentration of pretreated lignocellulosic waste in $0.05 \mathrm{M} \mathrm{Na}$-citrate buffer ( $\mathrm{pH}$ 5.0) at $50{ }^{\circ} \mathrm{C}$ for $4 \mathrm{~h}$. After enzymatic hydrolysis, it was centrifuged, and the supernatant was used to determine the amount of reducing sugars released from the pretreated lignocellulosic waste. The sample without enzyme was used as blank.

After lignocellulosic waste treatment with EG, the amount of reducing sugars $\left(\mathrm{mg} \mathrm{g}^{-1}\right)$ was determined by using the DNS method. The experiments were repeated three times. The results were evaluated using OriginPro 8.5 program by one-way Analysis of Variance (ANOVA) at a $5 \%$ significance level, and then Tukey's test was applied to the averages.

\section{Treatment of denim fabric with cellulase}

Desized cotton denim fabric from Bossa (TR) was used in this study. The cotton denim fabric $(2 \times 2$ $\mathrm{cm})$ was treated with enzyme at $\mathrm{pH} 5.0$ and $50{ }^{\circ} \mathrm{C}$ for $24 \mathrm{~h}$. Another piece of cotton denim fabric $(2 \times 2$ $\mathrm{cm})$ was treated without enzyme addition under same conditions as control. Enzyme activity was halted by incubating the fabric for 10 minutes in 80 ${ }^{\circ} \mathrm{C}$ water, and then washed in warm and cold water and dried at room temperature.

Scanning electron microscopy (SEM, a Tescan Vega-LSU instrument) was used to assess the surface morphology of the treated and untreated denim fabric. The micrographs were taken at X1 and X100 magnification level.

\section{Results and discussion}

\section{Cultivation of $T$. atroviride}

Isolated fungi was identified through molecular characterization. BLAST search was performed us- ing alignment of partial $18 S \mathrm{rRNA}$ gene (Fig. 1) isolated from fungi. Herewith, it exhibited maximum homology (99\%) with T. atroviride strain wxm143 (accession number: HM047763.1).

Fungi are favorable enzyme-producers among microbes because they are able to produce production of extracellular enzymes which are easy to recover from the fermentation broth. In this study, $T$. atroviride was used as EG-producer in a submerged system. Previously, Grigorevski-Lima et al. ${ }^{20}$ used the wild strain of $T$. atroviride in their study, and identified it as a promising producer of lignocellulolytic enzymes (EG, FPase, xylanase, $\beta$-glucosidase). Although submerged fermentation can lead to product dilution and decreasing of enzyme stability, it is advantageous in terms of process control and easy recovery of extracellular enzymes, mycelia or spores. $^{21}$ In previous studies, most of the enzyme production from $T$. atroviride had been performed using submerged fermentation. ${ }^{20,22,23,24}$ Moreover, submerged fermentation is still a prevalent method for cellulase production by fungi. ${ }^{25}$

The EG production was carried out at $35^{\circ} \mathrm{C}$, $\mathrm{pH} 5.0$ for six days. The EG activity was determined in culture medium from the second to sixth day of fermentation. It was determined that EG production reached maximum $\left(1.75 \mathrm{EU} \mathrm{mL}^{-1}\right)$ on the fifth day of fermentation (Fig. 2). After that, the enzyme activity decreased. There are several studies on the production of EG using different carbon sources. Oliveira et al. obtained EG activity of 1.37 EU $\mathrm{mL}^{-1}$ and $1.59 \mathrm{EU} \mathrm{mL}^{-1}$ using T. atroviride 679 and T. atroviride NTG21, respectively. ${ }^{24}$ Grigorevski-Lima et al. determined the maximum EG activity for T. atroviride 679 using untreated sugarcane bagasse as $1.9 \mathrm{EU} \mathrm{mL} \mathrm{mL}^{-1} .{ }^{20}$ Odeniyi et al. determined that EG activity was 0.096 EU (1.6 nkat) in submerged fermentation. ${ }^{26}$

\section{Purification of EG}

After removal of the cell from the culture medium, the EG was purified from supernatant obtained by ammonium sulfate precipitation, Sephadex G-100 and DEAE-Sephadex column. The

$>$ Trichoderma atroviride

ATTTCCATGGTCATACGTGCAGTGATCGAGGTCACATTTCAGAAGTTGGGTGTTTAACGGCTGTGGACGCGCC GCGCTCCCGATGCGAGTGTGCAAACTACTGCGCAGGAGAGGCTGCGGCGAGACCGCCACTGTATTTCGGAGA CGGCCACCCGCTAAGGGAGGGCCGATCCCCAACGCCGACCCCCCGGAGGGGTTCGAGGGTTGAAATGACGCT CGGACAGGCATGCCCGCCAGAATACTGGCGGGCGCAATGTGCGTTCAAAGATTCGATGATTCACTGAATTCTG CAATTCACATTACTTATCGCATTTCGCTGCGTTCTTCATCGATGCCAGAACCAAGAGATCCGTTGTTGAAAGTTT TGATTCATTTTCGAAACGCCTACGAGAGGCGCCGAGAAGGCTCAGATTATAAAAAAACCCGCGAGGGGGTAT ACAATAAGAGTTTTAGGTTGGTCCTCCGGCGGGCGCCTTGGTCCGGGGCTGCGACGCACCCGGGGCAGAGAT CCCGCCGAGGCAACAGTTTGGTAACGTTCACATTGGGTTTGGGAGTTGTAAACTCGGTAATGATCCCTCCGCA GGTACCCCTACCGGAAGGGTTACCAAAAATTTCCT

Fig. 1 - Alignment of partial $18 S$ rRNA gene isolated from T. atroviride 


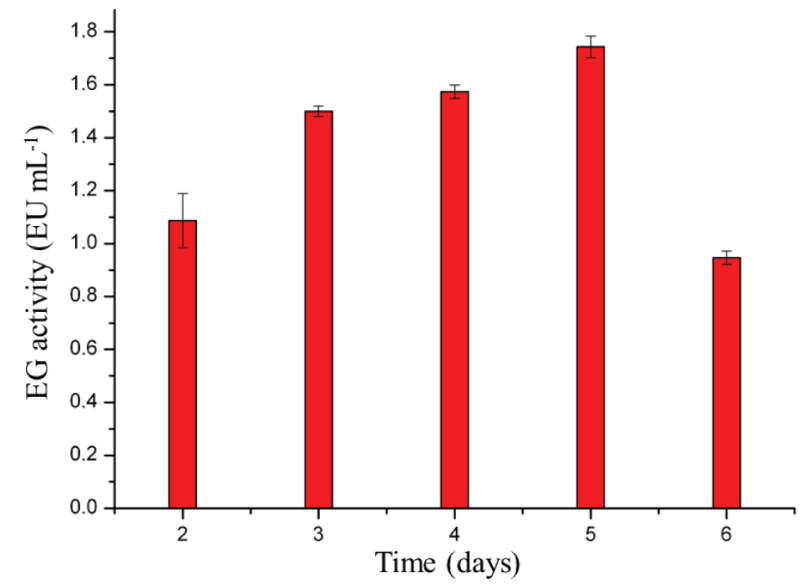

Fig. 2 - Determination of optimum day for enzyme production from $T$. atroviride. Each value represents the mean $\pm S D$ for three determinations.

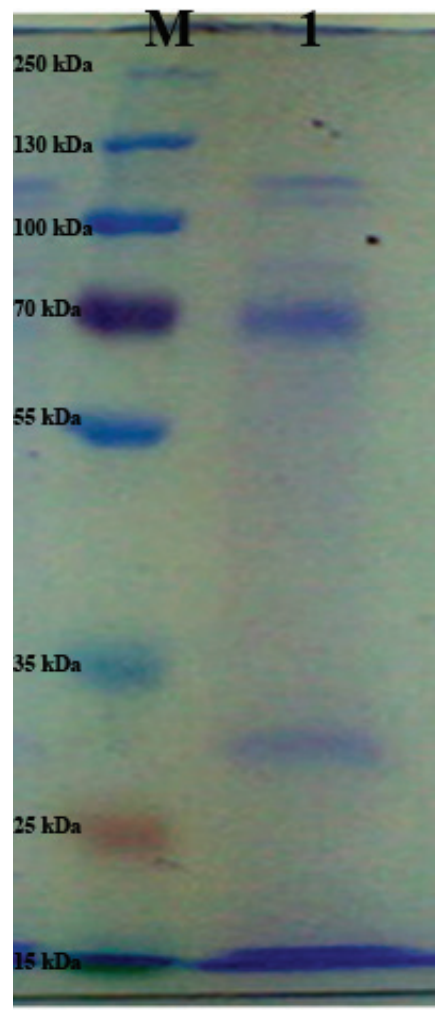

Fig. 3 - SDS PAGE bands of EG produced by T. atroviride M. Marker; $250 \mathrm{kDa}, 130 \mathrm{kDa}, 100 \mathrm{kDa}, 70 \mathrm{kDa}$ (pink band), $55 \mathrm{kDa}, 35 \mathrm{kDa}, 25 \mathrm{kDa}$ (orange band), $15 \mathrm{kDa}$ (green band). specific activity of purified enzyme was $30.9 \mathrm{EU} \mathrm{mg}^{-1}$ and a yield of $0.35 \%$. The purification procedure is summarized in Table 1. After purification, the obtained enzyme solution was concentrated 10-fold with lyophilization before native PAGE and SDS-PAGE.

The specific activity of EG from different types of microorganisms was examined from the Comprehensive Enzyme Information System. ${ }^{27}$ The specific activity values of EG (EU $\mathrm{mg}^{-1}$ ) changed from 0.018 (Thermobifida fusca) to 4240 (Streptomyces ruber). This value was $0.258 \mathrm{EU} \mathrm{mg}^{-1}$ for Trichoderma viride and $68 \mathrm{EU} \mathrm{mg}^{-1}$ for Trichoderma longibrachiatum. ${ }^{27}$ Usage of different kinds of substrate can effect specific activity. ${ }^{28}$

While the purified and lyophilized enzyme appeared as six bands in SDS-PAGE (Fig. 3), it appeared as three bands in native-PAGE (Fig. 4b) and the two of them had shown EG activity in the zymogram (Fig. 4a).

Earlier, Coral et al. ${ }^{29}$ had reported that there were two bands in SDS PAGE of CMCase from $A s$ pergillus niger Z10. Kumar et al. ${ }^{30}$ identified two bands of CMCase weighted at 34 and $26.5 \mathrm{kDa}$ in SDS PAGE, and explained that cellulase is a heteromeric multienzyme complex, and these might correspond to domains belonging to the purified enzyme in SDS-PAGE. ${ }^{30}$

\section{Optimum pH and temperature}

At $\mathrm{pH}$ 5.0, EG activities were measured at various temperatures from $30{ }^{\circ} \mathrm{C}$ to $70{ }^{\circ} \mathrm{C}$ in order to determine the optimum temperature. EG showed maximum enzyme activity at $50{ }^{\circ} \mathrm{C}$ (Fig. 5a). Enzymes can be classified into three groups, hyperthermophilic $\left(>80^{\circ} \mathrm{C}\right)$, thermophilic $\left(50^{\circ} \mathrm{C}-80^{\circ} \mathrm{C}\right)$, and mesophilic $\left(40{ }^{\circ} \mathrm{C}-60{ }^{\circ} \mathrm{C}\right)$ depending on the optimum temperature. It is proposed that fungiobtained endoglucanase has mesophilic properties. ${ }^{5}$

While the cellulases from $A$. terreus DSM 826 and A. glaucus XC9 have optimum temperature $\left(50{ }^{\circ} \mathrm{C}\right)$ similar to our enzyme ${ }^{3,5}$, the EG from $T$. atroviride 676 has higher optimum temperature. ${ }^{20}$ Tao et al. had indicated that T. reesei, the most popular industrial cellulase producer, has optimum temperature at $52{ }^{\circ} \mathrm{C} . .^{5}$

Table 1 - Summary of the purification of endo- $\beta$-1,4-glucanase from T. atroviride

\begin{tabular}{c|c|c|c|c|c}
\hline Step & $\begin{array}{c}\text { Total protein } \\
(\mathrm{mg})\end{array}$ & $\begin{array}{c}\text { Total activity } \\
(\mathrm{EU})\end{array}$ & $\begin{array}{c}\text { Specific activity } \\
\left(\mathrm{Eu} \mathrm{mg}^{-1}\right)\end{array}$ & $\begin{array}{c}\text { Yield } \\
(\%)\end{array}$ & $\begin{array}{c}\text { Purification } \\
\text { fold }\end{array}$ \\
\hline $\begin{array}{c}\text { supernatant } \\
\text { ammonium }\end{array}$ & 593.4 & 1066.05 & 0.56 & 100 & 1 \\
$\begin{array}{c}\text { sulfate precipitation }(60-80 \%) \\
\text { column chromatography }\end{array}$ & 15.75 & 2.94 & 5.36 & 2.65 & 9.57 \\
ion exchange chromatography & 3.13 & 0.26 & 12.04 & 0.53 & 21.5 \\
\hline
\end{tabular}




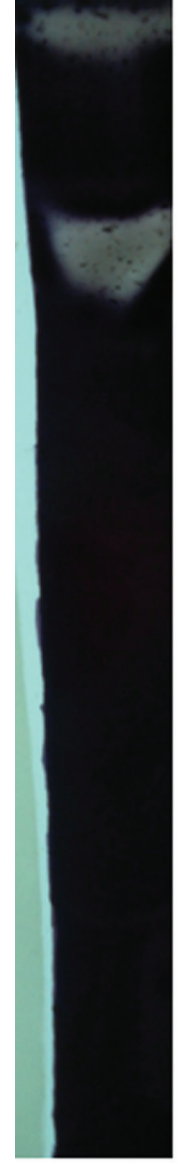

a

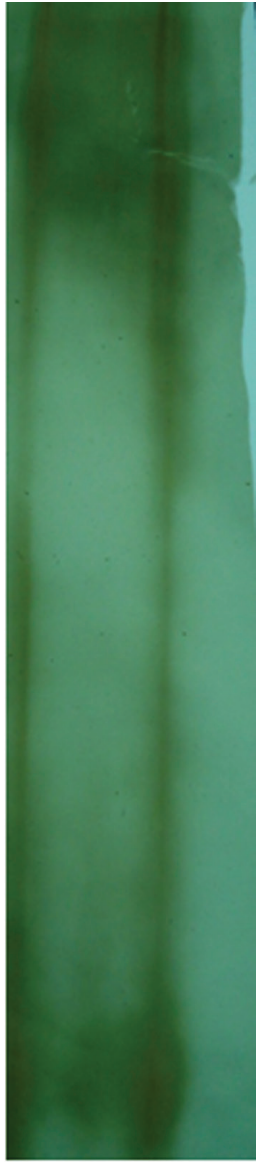

b
Fig. 4 - (a) Zymogram test of $E G$ (b) Native PAGE of EG

The optimum $\mathrm{pH}$ of EG activity for hydrolysis of $\mathrm{CMC}$ at $50{ }^{\circ} \mathrm{C}$ was determined. EG from T. atroviride showed maximum enzyme activity at $\mathrm{pH} 5.0$ (Fig. 5b). Because the EG from T. atroviride showed optimum activity at $\mathrm{pH} 5.0$, it can be said that the obtained enzyme has acidic properties according to Araǔjo et al. ${ }^{31}$

The optimum $\mathrm{pH}$ of this enzyme obtained from T. atroviride was same as that from $A$. aculeatus ${ }^{32}$ and differed slightly from $T$. atroviride $676(\mathrm{pH}$ 4.0), ${ }^{20}$ T. reesei QM-9414 ( $\left.\mathrm{pH} 4.5\right),{ }^{33}$ A. terreus DSM 826 (pH 4.8) ${ }^{3}$, and A. glaucus XC9 (pH 4.0). ${ }^{5}$

Usage of acidic cellulases is more suitable for degradation of lignocellulosic materials, and biostoning and finishing of cellulosic fibers in the textile industry. ${ }^{34,35}$ It is suggested that this enzyme is convenient for potential industrial processes under conditions of optimum temperature and $\mathrm{pH}$.

\section{Thermal stability}

High adsorption capacity, catalytic efficiency, and thermal stability are distinctive factors for cel-
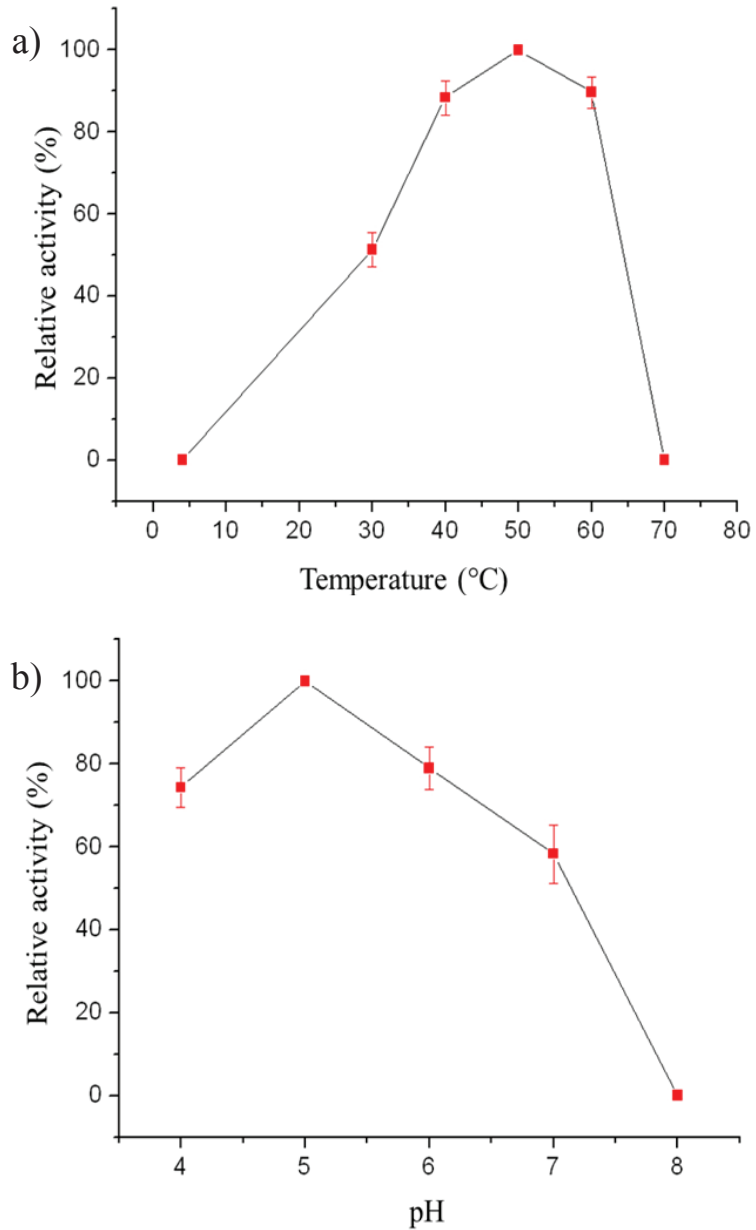

Fig. 5-Effect of temperature (a) and $p H$ (b) on the EG. Each value represents the mean $\pm S D$ for three determinations.

lulases in industrial applications. ${ }^{35}$ Thermal stability of the EG was determined as described in materials and methods (at $50{ }^{\circ} \mathrm{C}, \mathrm{pH} 5.0$ ). The EG activity sustained up to $72 \mathrm{~h}$, it lost only $9.5 \%$ of its initial activity at the end of this time (Fig. 6). As shown in Table 6, EG from $T$. atroviride had better thermal stability in relation to most of the EGs from other fungi reported in previous studies.

\section{Kinetic parameters}

The effect of substrate concentration on EG rate for CMC was determined. The Michaelis-Menten constant $\left(K_{\mathrm{m}}\right)$ and maximum velocity $\left(V_{\max }\right)$ were calculated from Lineweaver-Burk plots. $K_{\mathrm{m}}$ and $V_{\max }$ values of the $\mathrm{EG}$ for $\mathrm{CMC}$ hydrolysis were $1.12 \mathrm{mg} \mathrm{mL}^{-1}$ and $6.7 \mu \mathrm{mol}$ glucose $\mathrm{min}^{-1} \mathrm{~mL}^{-1}$, respectively (Fig. 7).

The obtained $K_{\mathrm{m}}$ value was relatively lower as compared to Penicillium pinophilum, T. harzianum ETS 323, and A. glaucus XC9 (Table 6). This suggested that the EG from $T$. atroviride showed good affinity towards $\mathrm{CMC}$. 


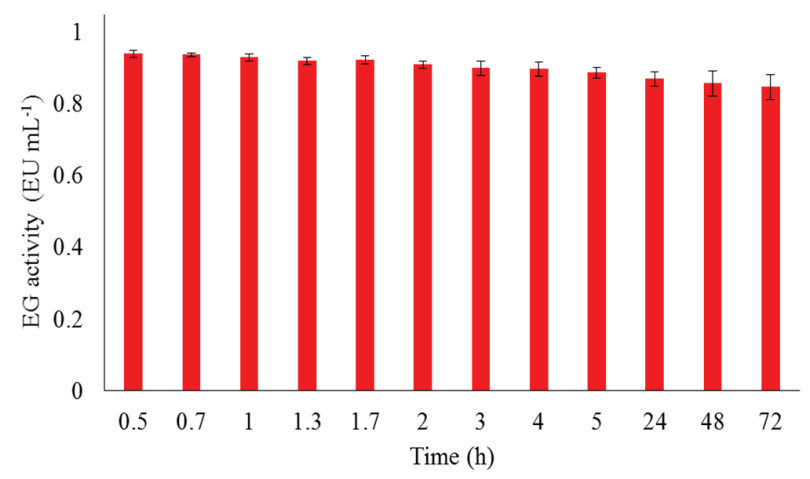

Fig. 6 - Thermal stability of the $E G\left(\right.$ at $50{ }^{\circ} \mathrm{C}, \mathrm{pH}$ 5.0). Each value represents the mean $\pm S D$ for three determinations.

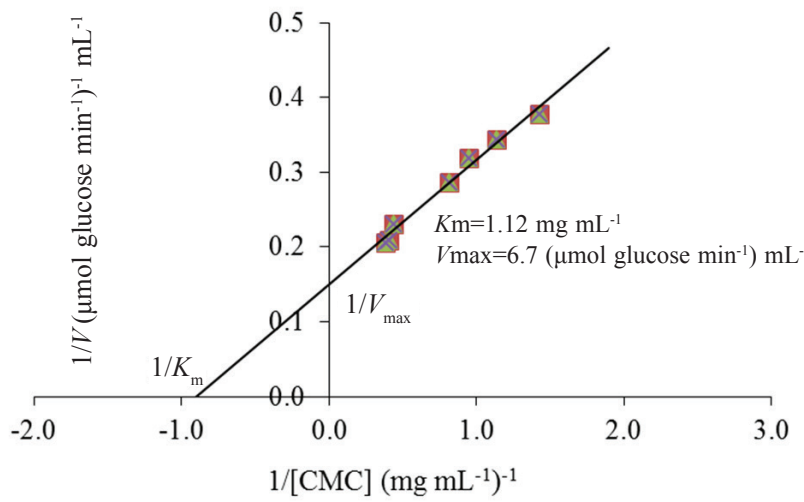

Fig. 7 - Lineweaver-Burk graph for determination of $K_{m}$ and $V_{\max }$ using $C M C$ as substrate

\section{Substrate specificity}

The substrate specificity of EG toward avicel, cellulose, cellobiose, wheat bran, filter paper, and CMC were determined. While the purified enzyme showed the highest activity against $\mathrm{CMC}$, the activity toward avicel, cellulose, filter paper, and WB were lower (Table 2).

\section{Effects of some metal ions on hydrolysis}

The effect of metal ions on hydrolysis may be due to changes in the electrostatic bonding, which are responsible for changes in the conformation of the enzyme. ${ }^{36,37}$ Metal ions can cause either inhibition of enzyme or activation, based on the nature of

Table 2 - Activity for different substrate of T. atroviride EG

\begin{tabular}{l|c}
\hline \multicolumn{1}{c|}{ Substrate } & $\begin{array}{c}\text { Specific activity } \\
\left(\mathrm{EU} \mathrm{mg}^{-1}\right)\end{array}$ \\
\hline CMC & 30.9 \\
wheat bran & 14.2 \\
avicel & 4.2 \\
cellulose & 3.8 \\
filter paper & 3.8 \\
\hline
\end{tabular}

the cations. ${ }^{36}$ Determining the effect of metal ions on enzyme hydrolysis is important because many industrial applications require their addition at various stages of the process, and the greater part of the enzymes requires a specific metal ion as a cofactor for their catalytic activity. ${ }^{36,38}$

Experiments were conducted in the activity method described above with different concentrations of various salt ions. Effects of the metal ions on the enzyme activity for hydrolysis of CMC are shown in Table 3.

EG was able to retain $44 \%$ and $47 \%$ of the EG initial activity in the presence of $36.10^{-3} \mathrm{M} \mathrm{MgCl}_{2}$ and $57.10^{-3} \mathrm{M} \mathrm{MgSO}$, respectively (Fig. 8a and $8 b$ ). Inhibition effect of $\mathrm{Mg}^{2+}$ may be explained with the presence of at least one sulfhydryl group in the active site. ${ }^{39}$ In previous studies, $\mathrm{MgCl}_{2}$ and $\mathrm{MgSO}_{4}$ inhibited the EG from Bacillus cereus and A. terreus, respectively. ${ }^{3,63}$

$\mathrm{NaCl}$ was studied between $3 \cdot 5 \cdot 10^{-3} \mathrm{M}-14 \cdot 4 \cdot 10^{-3}$ M (Fig. 8c). According to our results, the EG was activated with $\mathrm{NaCl}$ up to $14.4 \cdot 10^{-3} \mathrm{M}$. It was reported that $\mathrm{Na}^{+}$had no effect on EG from $A$. glaucus XC9, but activated EG from Cellulomanas sp. YJ5. ${ }^{5,40}$ Sinegani and Emtiazi ${ }^{41}$ indicated that endoglucanase activity activated in the presence of $\mathrm{Na}^{+}$.

Table 3 -Effects of metal ions and surfactants on hydrolysis

\begin{tabular}{|c|c|c|}
\hline Chemicals & $\begin{array}{l}\text { Relative } \\
\text { activity } \\
(\%)\end{array}$ & $\begin{array}{c}\text { Inhibition / } \\
\text { activation }\end{array}$ \\
\hline \multicolumn{3}{|l|}{ salt ions } \\
\hline $\operatorname{MgCl}_{2}\left(36 \cdot 10^{-3} \mathrm{M}\right)$ & 44 & inhibition \\
\hline $\mathrm{NaCl}\left(14.4 \cdot 10^{-3} \mathrm{M}\right)$ & 107 & activation $^{\mathrm{a}}$ \\
\hline $\mathrm{KCl}$ & - & $\mathrm{NE}$ \\
\hline $\mathrm{CoCl}_{2}$ & - & NE \\
\hline $\mathrm{CuCl}_{2}$ & - & $\mathrm{NE}$ \\
\hline $\mathrm{BaCl}_{2}$ & - & NE \\
\hline $\mathrm{CaCl}_{2}$ & - & NE \\
\hline $\mathrm{FeCl}_{3}$ & - & NE \\
\hline $\mathrm{MgSO}_{4}\left(57 \cdot 10^{-3} \mathrm{M}\right)$ & 47 & inhibition \\
\hline $\mathrm{MnSO}_{4}$ & - & NE \\
\hline $\mathrm{FeSO}_{4}$ & - & $\mathrm{NE}$ \\
\hline $\mathrm{CuSO}_{4}$ & - & NE \\
\hline \multicolumn{3}{|l|}{ surfactants } \\
\hline tween $80\left(2 \cdot 10^{-2} \mathrm{w} / \mathrm{v}\right)$ & 127 & activation $^{\mathrm{b}}$ \\
\hline triton $\mathrm{x}-100\left(3.6 \cdot 10^{-3} \mathrm{w} / \mathrm{v}\right)$ & 123 & activation $^{\mathrm{c}}$ \\
\hline \multicolumn{3}{|l|}{ biosurfactants } \\
\hline total saponin I $\left(0.09 \mathrm{mg} \mathrm{mL}^{-1}\right)$ & 125 & activation \\
\hline total saponin II $\left(0.09 \mathrm{mg} \mathrm{mL}^{-1}\right)$ & 116 & activation \\
\hline total saponin III $\left(0.09 \mathrm{mg} \mathrm{mL}^{-1}\right)$ & 163 & activation \\
\hline
\end{tabular}



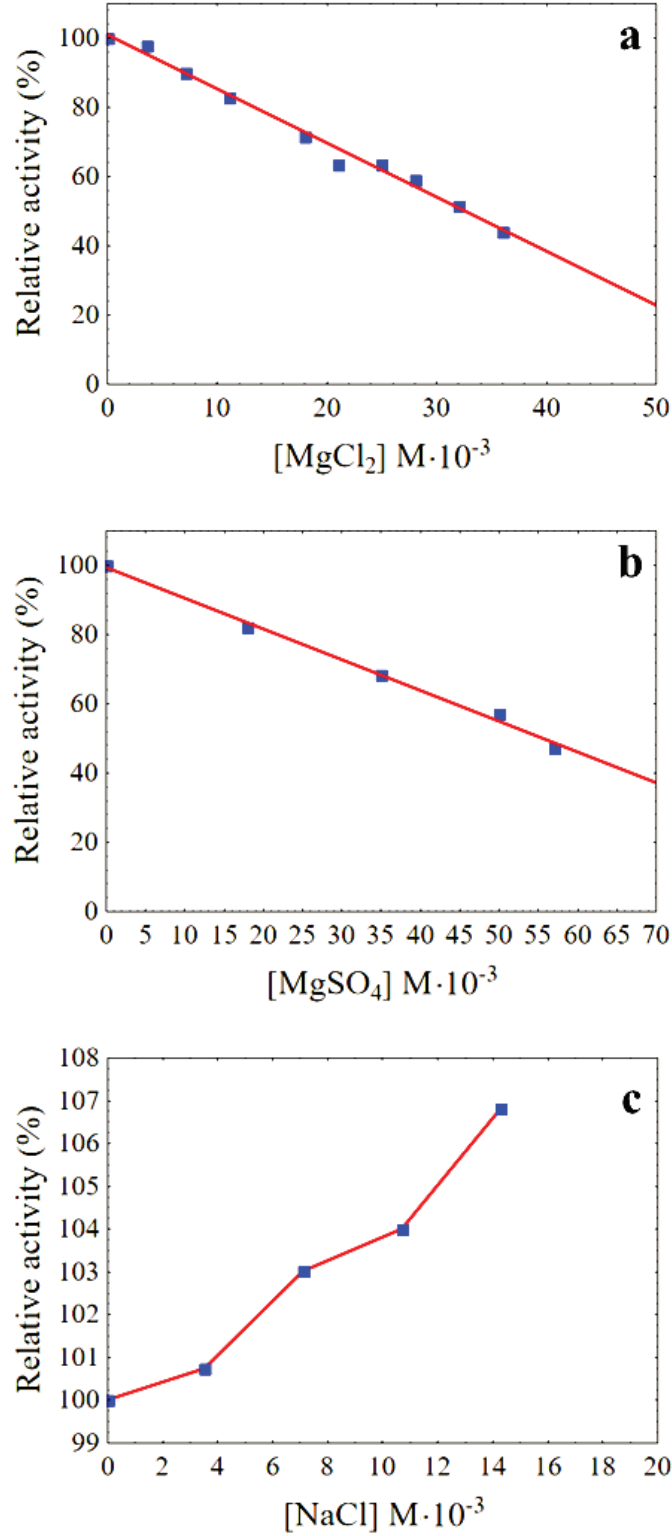

Fig. 8 - Effects of $\mathrm{MgCl}_{2}(\mathrm{a}), \mathrm{MgSO}_{4}(b)$, and $\mathrm{NaCl}(\mathrm{c})$ on $\mathrm{EG}$ activity

Salt ions prevent the enzyme from forming random hydrogen bonds and provide accessibility to active sites for substrate. ${ }^{42}$

\section{Effects of surfactants and biosurfactants, total saponins on hydrolysis}

EG activity was activated by increasing concentrations of Tween 80 and Triton X-100 (Table 3 and Fig. 9a, 9b).

It has been determined in previous studies that several surfactants such as nonionic Tween 20, 80, 81 and polyethylene glycol, cationic Q-86W, sophorolipid, rhamnolipid, and bacitracin had enhanced cellulose hydrolysis. The surfactant enabled creation of a hydrophilic environment on cellulose surface and thereby, it is provided that the irreversible
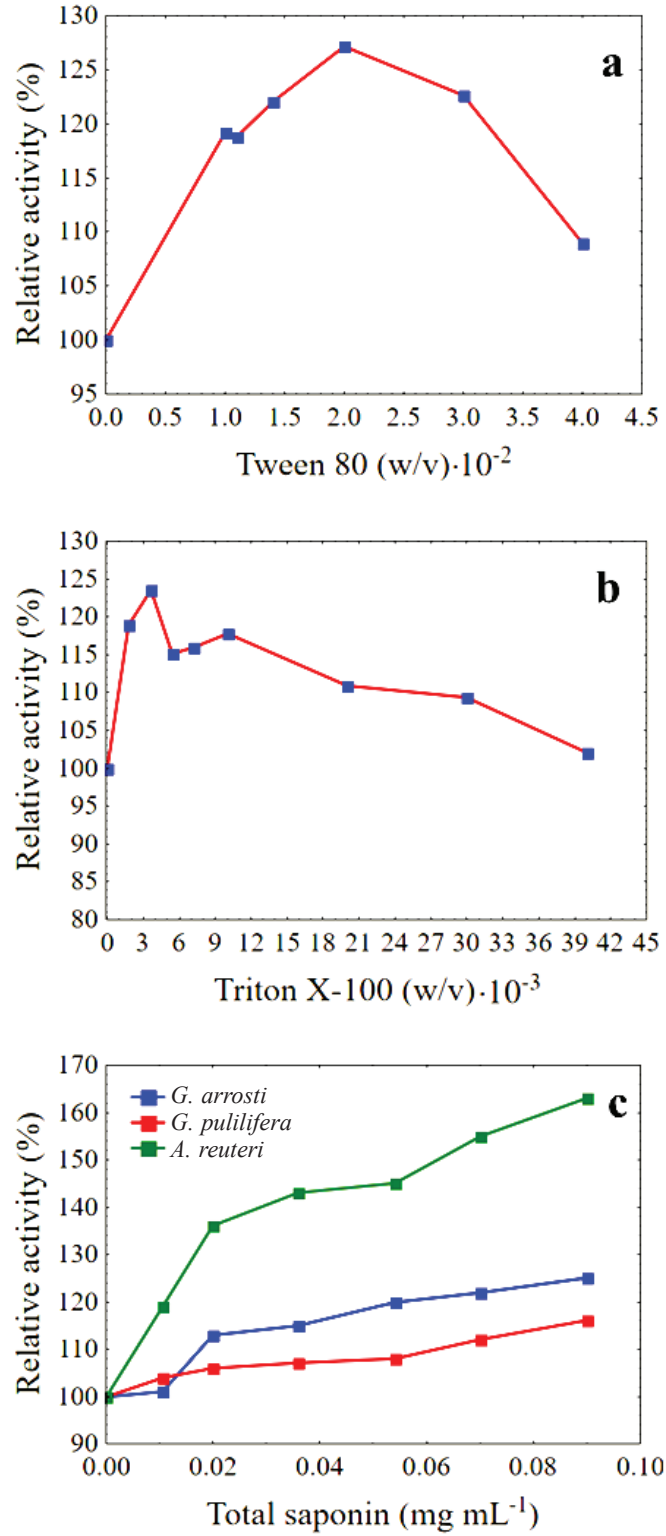

Fig. 9 - Effects of Tween 80 (a), Triton X-100 (b), and total saponins as biosurfactants (c) on EG activity

binding of cellulase on cellulose decreased and enzyme activity increased. ${ }^{43,44}$

Saponins are glycosides with a distinctive foaming characteristic. They are found in many plants, the roots of which give soap-like foams in water. They consist of a polycyclic aglycone containing a choline steroid or triterpenoid. ${ }^{45}$ The Gypsophila arrostii Guss. var. nebulosa (Boiss. \& Heldr.) (Total saponin I), Gypsophila pilulifera Boiss. \& Heldr. (Total saponin II), and Ankyropetalum reuteri Fenzl. Boiss. (Total saponin III), are typical Turkish varieties, naturally found in a particular area in the Mediterranean and Southeast zone of Turkey. These species are rich a source of triterpene saponins, and can be used to enhance activity of the EG (Table 3), which makes the process less economically feasible. 
Fig. 9c shows that the total saponins had a beneficial effect on EG activity. When we compared chemical surfactants and biosurfactants as total saponin, it was observed that biosurfactants are more effective for increasing EG activity. Especially, Ankyropetalum reuteri Fenzl. Boiss. (Total saponin III) increased EG activity about $60 \%$. It has been reported in the previous studies that surfactants were the most suitable additives for improving the saccharification of lignocellulose and the recovery of cellulolytic. ${ }^{46,47}$

Although studies have been reported on the effect of saponins from different plants on cellulose, ${ }^{48,49}$ to our knowledge, no research paper is available on the effect of saponins from Gypsophila arrostii Guss. var. nebulosa (Boiss. \& Heldr.), Gypsophila pilulifera Boiss. \& Heldr. and Ankyropetalum reuteri Fenzl. Boiss. on EG from T. atroviride. It was suggested that these natural saponins as non-ionic surfactants can be used together with cellulase in the industrial process. It is known that using cellulase in industry makes the process highly costly. The enzyme loading could be reduced by adding an appropriate concentration of these total saponins in the reaction mixture. In this way, the process could be economically viable.

\section{Effect of the EG on the pretreated lignocellulosic waste}

In this study, the influences of two various chemical pretreatments, as alkaline and acidic, have been compared. The effects of EG on sawdust and WB pretreated with $\mathrm{NaOH}$ and $\mathrm{H}_{2} \mathrm{SO}_{4}$ are shown as the amount of reducing sugars $\left(\mathrm{mg} \mathrm{g}^{-1}\right)$ in Table 4 . The results indicated that pretreatment with different concentrations of $\mathrm{NaOH}$ and $\mathrm{H}_{2} \mathrm{SO}_{4}$ significantly $(p<0.05)$ altered the amount of reducing sugars released from poplar and WB compared to the untreated control (Table 5). While the EG had no effect on non-pretreatment sawdust, had little effect on the non-pretreatment WB. The released amount of reducing sugars was maximal for poplar and WB pretreated with alkali method. Previously, it has been stated that alkaline pretreatments are more effective than acidic pretreatment, and pretreatment

Table 4 -Effects of EG to sawdusts and WB pretreated with $\mathrm{NaOH}$ and $\mathrm{H}_{2} \mathrm{SO}_{4}$

\begin{tabular}{l|c|c|c|c}
\hline & Poplar & Wheat bran & Calabrian pine & Abies pine \\
\cline { 2 - 5 } & $\begin{array}{c}\text { Amount of reducing } \\
\text { sugar }\left(\mathrm{mg} \mathrm{g}^{-1}\right)\end{array}$ & $\begin{array}{c}\text { Amount of reducing } \\
\text { sugar }\left(\mathrm{mg} \mathrm{g}^{-1}\right)\end{array}$ & $\begin{array}{c}\text { Amount of reducing } \\
\text { sugar }\left(\mathrm{mg} \mathrm{g}^{-1}\right)\end{array}$ & $\begin{array}{c}\text { Amount of reducing } \\
\text { sugar }\left(\mathrm{mg} \mathrm{g}^{-1}\right)\end{array}$ \\
\hline control (distilled water) & $0 \pm 0.00$ & $4.6 \pm 0.40$ & $0 \pm 0.00$ & $0 \pm 0.00$ \\
$0.5 \mathrm{M} \mathrm{NaOH}$ & $6 \pm 0.50$ & $15.4 \pm 1.47$ & $0 \pm 0.00$ & $0 \pm 0.00$ \\
$1 \mathrm{M} \mathrm{NaOH}$ & $6.4 \pm 1.13$ & $16 \pm 0.23$ & $0 \pm 0.00$ & $0 \pm 0.00$ \\
$0.05 \mathrm{M} \mathrm{H}_{2} \mathrm{SO}_{4}$ & $3 \pm 0.67$ & $10.4 \pm 0.57$ & $0 \pm 0.00$ & $0 \pm 0.00$ \\
$0.1 \mathrm{M} \mathrm{H}_{2} \mathrm{SO}_{4}$ & $3.4 \pm 0.35$ & $12.4 \pm 0.44$ & $4 \pm 0.07$ & $3 \pm 0.26$ \\
\hline
\end{tabular}

Table 5 -Statistical comparisons of the pretreatment methods

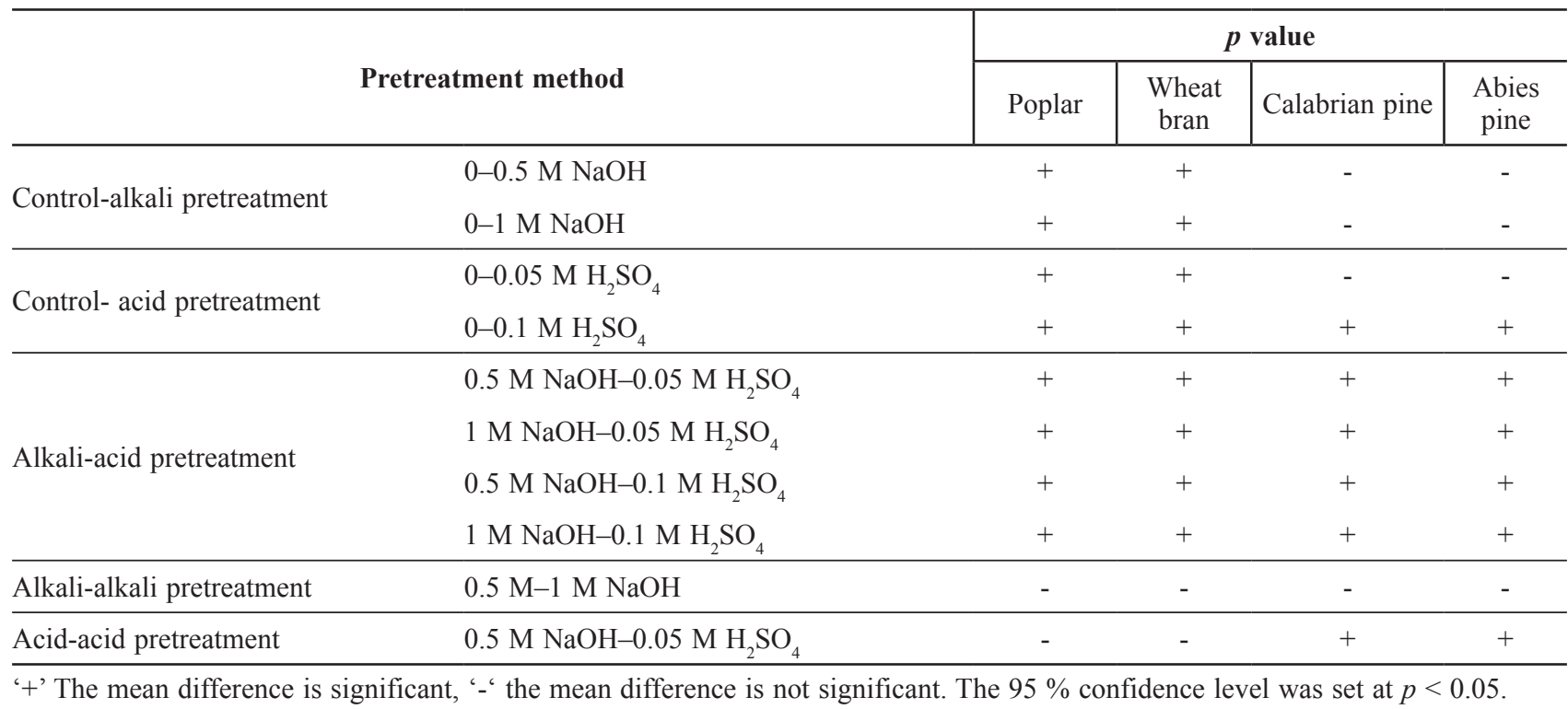


with sodium hydroxide has attracted most attention. ${ }^{52,53}$ All pretreatment methods used, except for $0.1 \mathrm{M} \mathrm{H}_{2} \mathrm{SO}_{4}$, had not significantly altered the amount of reducing sugars released from calabrian pine and abies pine compared to the non-treated control $(p>0.05)$.

Poplar is hardwood (contains $40-55 \%$ cellulose, 24-40\% hemicellulose, $18-25 \%$ lignin), calabrian pine and abies pine are softwood (contains $45-50 \%$ cellulose, $25-35 \%$ hemicellulose, $25-35 \%$ lignin). ${ }^{44,50,51}$ It is suggested that, because poplar contains more cellulose and less lignin than the other, the removal of lignin using pretreatment methods can be easier and more effective than from other sawdust. From this point of view, WB contains less lignin than wood sawdust; therefore there has been an efficient increasing amount of released reducing sugars after pretreatment.

In conclusion, the concentration of $\mathrm{H}_{2} \mathrm{SO}_{4}$ had a significant $(p<0.05)$ effect on hydrolysis of calabrian pine and abies pine. Increasing the concentration of $\mathrm{H}_{2} \mathrm{SO}_{4}$ from $0.05 \mathrm{M}$ to $0.1 \mathrm{M}$ significantly increased the released amount of reducing sugars. The effectiveness of acid and alkali pretreatment methods was not concentration-dependent for poplar and WB (Table 5).

The millions of tons of lignocellulosic wastes produced worldwide, especially WB and sawdust obtained from agricultural industries, is an important source for the production of renewable fuels. ${ }^{1}$ Finally, we may say that the enzyme could benefit industrial processes such as the production of bioethanol used as economic and ecologic biofuel for transportation purposes.

\section{Denim fabric treatment with the EG}

In this study, the EG from $T$. atroviride was applied on a desized denim fabric and determined was its efficiency in producing the old look and the discolorization of the fabric (Fig. 10a and 10b). The cotton fabric treated with enzyme in Fig. 10b shows a more discolored surface than the fabric in Fig. 10a (no treatment with enzyme). Acidic cellulases are most commonly used in bio-stoning. ${ }^{54}$ The EG from T. atroviride was acidic enzyme and caused discoloration of the denim fabric, thus producing the old look.

Fig. 11a and 11b shows the SEM images of the untreated denim fabric and denim fabric treated with EG, respectively. It seems that the desized denim fabric (Fig. 11a) contains huge amounts of fuzz and pill on the surface. After EG treatment, the fuzz and pill on the denim fabric was removed from the surface (Fig. 11b). The SEM images suggest that the EG had not significantly disrupted the inner fibers of the treated denim fabric (Fig. 11b) because the inner fibers are less accessible to EG. ${ }^{55}$

Cellulases provide a better finishing procedure by removing fuzz and pill on the denim surface. In addition, they have been used in softening, defibrillation, an in the process of providing localized differences in the color density of fibers. ${ }^{54}$ Therefore, our results showed that the EG from $T$. atroviride had an effect for removing the fuzz indigo dye from the denim fabric and increased its softness. The obtained enzyme can be used for biostoning and denim finishing, without a notable harmful effect on the inner fibers. Similar results have been obtained by Montazer and Maryan..$^{5,56,57}$

\section{Conclusions}

The EG was obtained and characterized from a local isolate T. atroviride. Performed were SDS PAGE, native PAGE, and zymogram test. The EG had high specific activity toward CMC compared to

Table 6 -Comparison to EG obtained from previous studies with this EG

\begin{tabular}{|c|c|c|c|c|c|}
\hline fungus & $\begin{array}{l}\text { optimum } \\
\text { pH }\end{array}$ & $\begin{array}{l}\text { optimum } \\
\text { temperature }\end{array}$ & thermal stability & $K_{\mathrm{m}}$ & ref. \\
\hline C. sp. YJ5 & 7.0 & $60{ }^{\circ} \mathrm{C}$ & after $30 \mathrm{~min}$ incubation at $60^{\circ} \mathrm{C}$, retained activity $70 \%$ & - & 40 \\
\hline A. glaucus XC9 & 4.0 & $50{ }^{\circ} \mathrm{C}$ & after $1 \mathrm{~h}$ incubation at $60{ }^{\circ} \mathrm{C}$, retained activity $60 \%$ & $5 \mathrm{mg} \mathrm{mL}^{-1}$ & 5 \\
\hline A. aculeatus & 5.0 & $40{ }^{\circ} \mathrm{C}$ & after $1 \mathrm{~h}$ incubation at $60{ }^{\circ} \mathrm{C}$, retained activity $60 \%$ & - & 32 \\
\hline C. thermocellum & 7.0 & $70{ }^{\circ} \mathrm{C}$ & after $48 \mathrm{~h}$ incubation at $60^{\circ} \mathrm{C}$, retained activity $50 \%$ & - & 60 \\
\hline T. harzianum ETS 323 & 4.5 & $50{ }^{\circ} \mathrm{C}$ & after 10 days incubation at $38^{\circ} \mathrm{C}$, retained activity $100 \%$ & $23 \mathrm{mg} \mathrm{mL}^{-1}$ & 28 \\
\hline Penicillium pinophilum & 5.0 & $50{ }^{\circ} \mathrm{C}$ & after $6 \mathrm{~h}$ incubation at $50^{\circ} \mathrm{C}$, retained activity $100 \%$ & $4.8 \mathrm{mg} \mathrm{mL}^{-1}$ & 61 \\
\hline Mucor circinelloides & 5.0 & $55^{\circ} \mathrm{C}$ & after $30 \mathrm{~min}$ incubation at $70{ }^{\circ} \mathrm{C}$, retained activity $90 \%$ & - & 62 \\
\hline T. atroviride 676 & 4.0 & $60^{\circ} \mathrm{C}$ & after $8 \mathrm{~h}$ incubation at $50{ }^{\circ} \mathrm{C}$, retained activity $90 \%$ & - & 20 \\
\hline T. atroviride & 5.0 & $50{ }^{\circ} \mathrm{C}$ & after $72 \mathrm{~h}$ incubation at $50{ }^{\circ} \mathrm{C}$, retained activity $90.5 \%$ & $1.12 \mathrm{mg} \mathrm{mL}^{-1}$ & in this study \\
\hline
\end{tabular}

-: not reported 


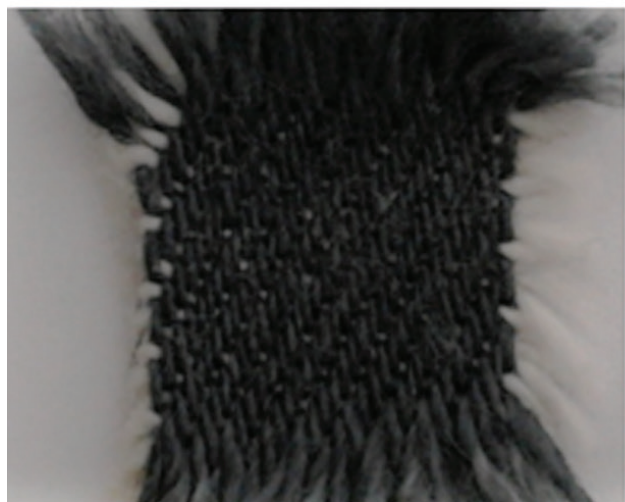

$\mathbf{a}$

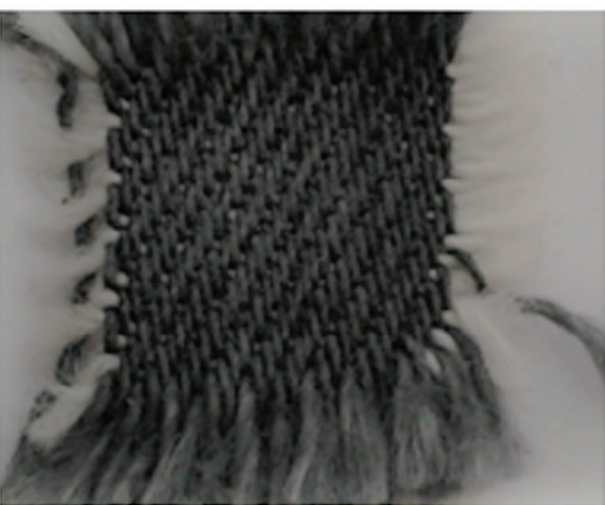

b

Fig. 10 - Photos of old-look appearance and discolorization of the fabric. (a) Only treated with $0.05 \mathrm{M}$ Na-citrate buffers ( $\mathrm{pH}$ 5.0). (b) Treated with EG in $0.05 \mathrm{M}$ Na-citrate buffers ( $p H$ 5.0).
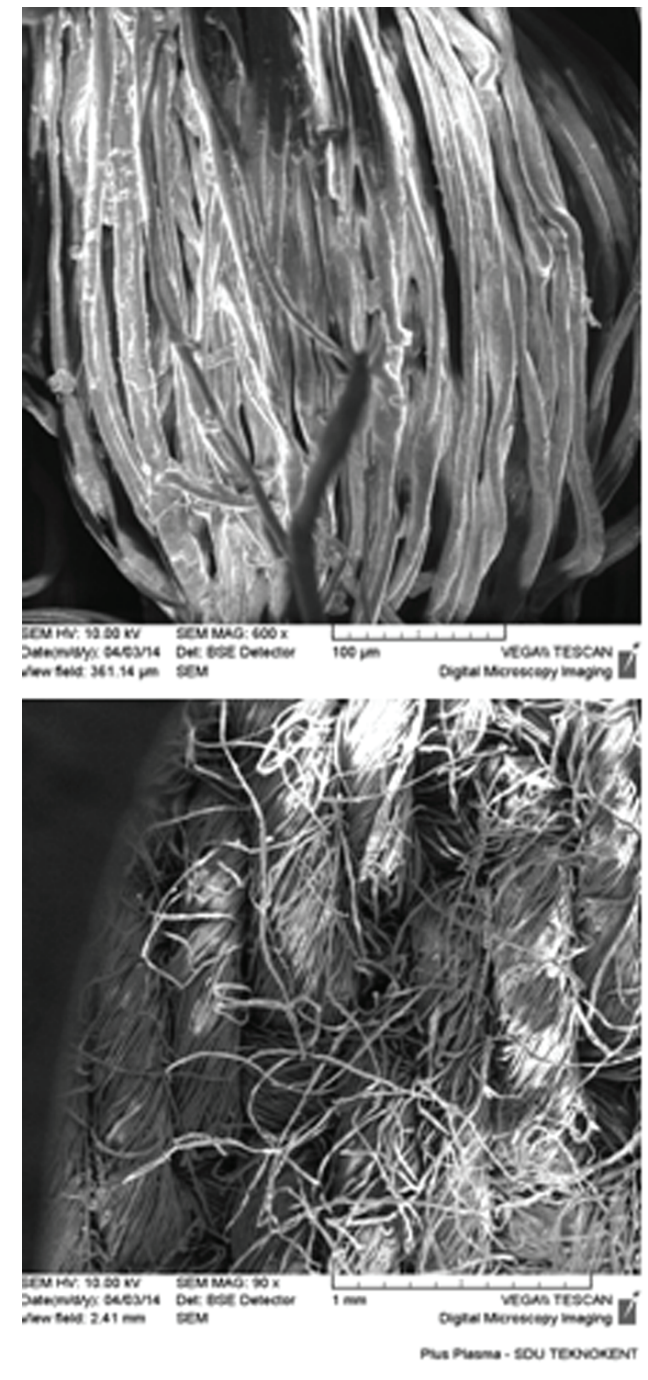

$\mathbf{a}$
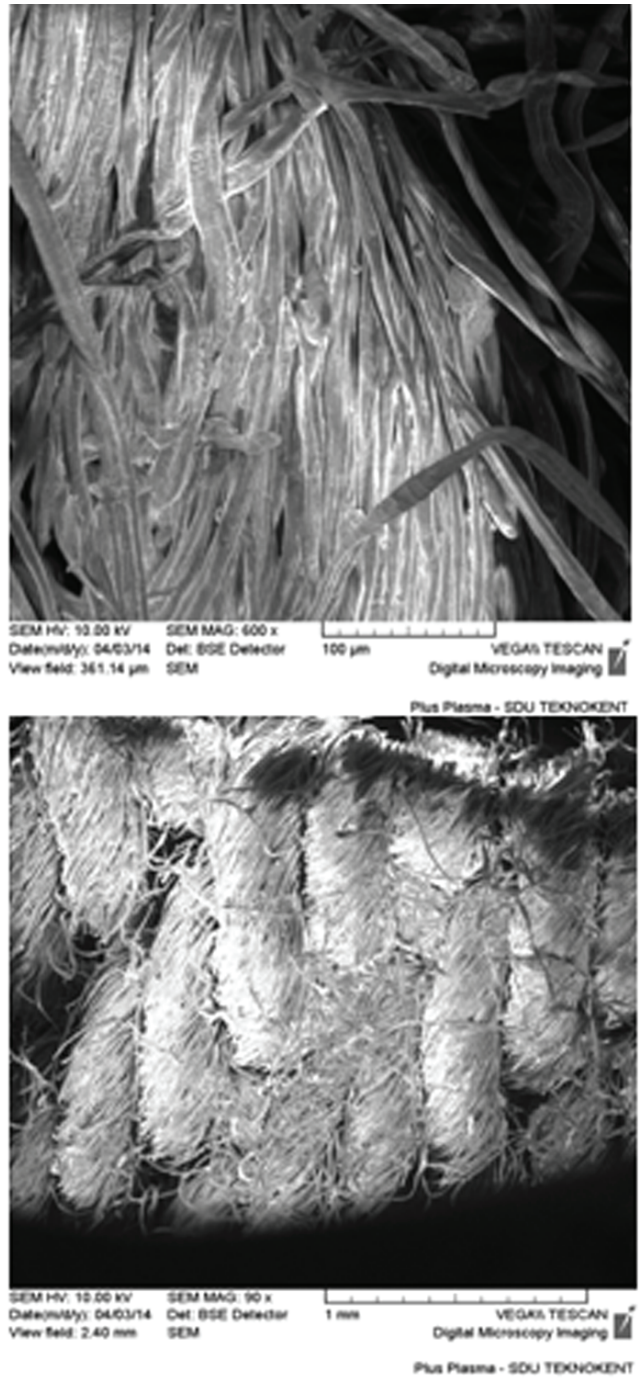

b

Fig. 11 - SEM images of denim fabric. (a) Only treated with $0.05 \mathrm{M}$ Na-citrate buffers ( $\mathrm{pH}$ 5.0). (b) Treated with EG in $0.05 \mathrm{M}$ Na-citrate buffers ( $\mathrm{pH}$ 5.0). 
EGs from A. aculeatus, ${ }^{32} A$. glaucus XC9, ${ }^{5} A$. niger ${ }^{58}$ Pseudomonas fluorescens, ${ }^{59}$ Clostridium thermocellum, ${ }^{60} T$. harzianum ETS $323,{ }^{28}$ and optimum activity at $\mathrm{pH} 5.0$ and $50{ }^{\circ} \mathrm{C}$. The EG sustained its activity up to $72 \mathrm{~h}$ at $50{ }^{\circ} \mathrm{C}$ and $\mathrm{pH} 5.0$, it lost only $9.5 \%$ of its initial activity. The obtained EG had adequate properties such as low $K_{\mathrm{m}}$ and high thermal stability for industrial applications compared to EG obtained from previous studies (Table 6).

While $\mathrm{MgCl}_{2}$ and $\mathrm{MgSO}_{4}$ inhibited the enzyme, $\mathrm{NaCl}$, Tween 80 , Triton $\mathrm{X}-100$ and total saponins from various plants activated it. Depending on the results obtained from biostoning and hydrolysis of pretreated lignocellulosic waste, it was suggested that the EG has useful properties for industrial applications and commercial purposes.

\section{ACKNOWLEDGEMENT}

This study was financially supported by the Council of Higher Education of Turkey (OYP05244-YL-12). We thank Halil Biyı from Adnan Menderes University and Dilek Ozdemir Kuçukçapraz from Suleyman Demirel University, Turkey.

\section{References}

1. Sánchez, C. Lignocellulosic residues: Biodegradation and bioconversion by fungi, Biotechnol. Adv. 27 (2004) 185. doi: http://dx.doi.org/10.1016/j.biotechadv.2008.11.001

2. Bansal, N., Tewari, R., Soni, R., Soni, S. K., Production of cellulases from Aspergillus niger NS-2 in solid state fermentation on agricultural and kitchen waste residues, Waste Manage. 32 (2012) 1341. doi: http://dx.doi.org/10.1016/j.wasman.2012.03.006

3. Elshafei, A. M., Hassan, M. M., Haroun, B. M., Abdel-Fatah, O. M., Atta, H. M., Othman, A. M., Purification and properties of an endoglucanase of Aspergillus terreus DSM 826, J. Basic Microb. 49 (2009) 426. doi: http://dx.doi.org/10.1002/jobm.200800227

4. Zhao, L., Guo, L., Xiao, H., Zheng, L., Wang, Y., Lin, J., Purification and Characterization of the Recombinant Multifunctional Cellulase from Volvariella volvacea, Food Biotechnol. 26 (2012) 164. doi: http://dx.doi.org/10.1080/08905436.2012.670890

5. Tao, Y., Zhu, X., Huang, J., Ma, S., Wu, X., Long, M., Chen, $Q$., Purification and properties of endoglucanase from a sugar cane bagasse hydrolyzing strain, Aspergillus glaucus XC9, J. Agric. Food Chem. 58 (2010) 6126. doi: http://dx.doi.org/10.1021/jf1003896

6. Tang, B., Pan, H., Tang, W., Zhang, Q., Ding, L., Zhang, F., Fermentation and purification of cellulase from a novel strain Rhizopus stolonifer var. reflexus TP-02, Biomass Bioenerg. 36 (2012) 366. doi: http://dx.doi.org/10.1016/j.biombioe.2011.11.003

7. Kim, B., Gulati, I., Park, J., Shin, J., Pretreatment of cellulosic waste sawdust into reducing sugars using mercerization and etherification, Bioresources.com 7(4) (2012) 5152.

8. Steffien, D., Aubel, I., Bertau, M., Enzymatic hydrolysis of pretreated lignocellulose with Penicillium verruculosum cellulases, J. Mol. Catal B-Enzym. 103 (2013) 29. doi: http://dx.doi.org/10.1016/j.molcatb.2013.11.004
9. Annamalaia, N., Rajeswarib, M. V., Elayarajab, S., Balasubramanian, T., Thermostable, haloalkaline cellulase from Bacillus halodurans CAS 1 by conversion of lignocellulosic wastes, Carbohyd. Polym. 94 (2013) 409. doi: http://dx.doi.org/10.1016/j.carbpol.2013.01.066

10. Sohail, M., Siddiqi, R., Ahmad, A., Khan, S. A., Cellulase production from Aspergillus niger MS82: Effect of temperature and pH, N. Biotechnol. 25(6) (2009) 437. doi: http://dx.doi.org/10.1016/j.nbt.2009.02.002

11. Dhillona, G. S., Kaura, S., Brara, S. K., Vermac. M., Potential of apple pomace as a solid substrate for fungal cellulase and hemicellulase bioproduction through solid-state fermentation, Ind. Crop. Prod. 38 (2012) 6. doi: http://dx.doi.org/10.1016/j.indcrop.2011.12.036

12. Bhat, M. K., Cellulases and related enzymes in biotechnology, Biotechnol. Adv. 18 (2000) 355. doi: http://dx.doi.org/10.1016/S0734-9750(00)00041-0

13. Anish, R., Rahman, M. S., Rao, M., Application of cellulases from an alkalothermophilic Thermomonospora sp. in biopolishing of denims, Biotechnol. Bioeng. 96 (2007) 48. doi: http://dx.doi.org/10.1002/bit.21175

14. Mandels, M., Weber, J., Production of cellulases, Adv. Chem. Series 95 (1969) 391.

doi: http://dx.doi.org/10.1021/ba-1969-0095.ch023

15. Ghose, T. K., Measurement of cellulase activities, Pure \& Appl. Chem. 59(2) (1987) 257. doi: http://dx.doi.org/10.1351/pac198759020257

16. Miller, G. L., Use of dinitrosalicylic acid reagent for determination of reducing sugar, Anal. Chem. 31 (1959) 426. doi: http://dx.doi.org/10.1021/ac60147a030

17. Laemmli, U. K., Cleavage of structural proteins during the assembly of the head of bacteriophage T4, Nature 227(5259) (1970) 680 . doi: http://dx.doi.org/10.1038/227680a0

18. Lowry, O. H., Rosebrough, N. J., Farr, A. L., Randall, R. J., Protein measurement with the folin phenol reagent, J. Biol. Chem. 193 (1951) 265.

19. Mandels, M., Hontz, L., Nystrom, J., Enzymatic hydrolysis of waste cellulose, Biotechnol. Bioeng. 16 (1974) 1471. doi: http://dx.doi.org/10.1002/bit.260161105

20. Grigorevski-Lima, A. L., Oliveira, M. M. Q., Nascimento, R. P., Bon, E. P. S., Coelho, R. R. R., Production and partial characterization of cellulases and xylanases from trichoderma atroviride 676 using lignocellulosic residual biomass, Appl. Biochem. Biotechnol. 169 (2013) 1373. doi: http://dx.doi.org/10.1007/s12010-012-0053-6

21. Sandhya, C., Sumantha, A., Szakacs, G., Pandey, A., Comparative evaluation of neutral protease production by $A s$ pergillus oryzae in submerged and solid-state fermentation, Process Biochem. 40 (2005) 2689. doi: http://dx.doi.org/10.1016/j.procbio.2004.12.001

22. Kaur, J., Munshi, G. D., Singh, R. S., Koch, E., Effect of Carbon Source on Production of Lytic Enzymes by the Sclerotial Parasites Trichoderma atroviride and Coniothyrium minitans, J. Phytopathology, 153 (2005) 274. doi: http://dx.doi.org/10.1111/j.1439-0434.2005.00969.x

23. Kovács, K., Szakacs, G., Zacchi, G., Comparative enzymatic hydrolysis of pretreated spruce by supernatants, whole fermentation broths and washed mycelia of Trichoderma reesei and Trichoderma atroviride, Bioresour. Technol. 100 (2009) 1350. doi: http://dx.doi.org/10.1016/j.biortech.2008.08.006

24. Oliveira, M. M. Q., Lima, A. L. G., Bon, S., E. P., Coelho, R. R. R., Nascimento, R., P., Production of thermophilic and acidophilic endoglucanases by mutant Trichoderma atroviride $102 \mathrm{C} 1$ using agro-industrial by-products, Afr. J. Biotechnol. 15 (2016) 423. 
25. Singhania, R. R., Sukumaran, R. K., Patel, A. K., Larroche, $C$., Pandey, A., Advancement and comparative profiles in the production technologies using solid-state and submerged fermentation for microbial cellulases, Enzyme Microb. Technol. 46 (2010) 541. doi: http://dx.doi.org/10.1016/j.enzmictec.2010.03.010

26. Odeniyi, O. A., Onilude, A. A., Ayodele, M. A., Characteristics of a $\beta-1,4-\mathrm{D}$ endoglucanase from trichoderma virens wholly applied in a palm-fruit husk-based diet for poultry layers, Braz. J. Microbiol. 2012 (2012) 1467. doi: http://dx.doi.org/10.1590/S1517-83822012000400031

27. URL: http://www.brenda-enzymes.info/enzyme.php?ecno=3.2.1.4\#SPECIFIC ACTIVITY $\quad[\mu \mathrm{mol} / \mathrm{min} / \mathrm{mg}]$ (21.04.2016)

28. Liu, S., Shibu, M. A., Jhan, H., Lo, C., Peng, K., Purification and characterization of novel glucanases from Trichoderma harzianum ETS 323, J. Agric. Food Chem. 58 (2010) 10309. doi: http://dx.doi.org/10.1021/jf1029338

29. Coral, G., Arıkan, B., Unald, M. N., Guvenmez, H., Some properties of crude carboxymethyl cellulase of Aspergillus niger Z10 wild-type strain, Turk J. Biol. 26 (2002) 209

30. Kumar, D., Ashfaque, M., Muthukumar, M., Singh, M., Garg, R., Production and characterization of carboxymethyl cellulase from Paenibacillus polymyxa using mango peel as substrate, J. Environ. Biol. 33 (2012) 81.

31. Araǔjo, R., Casal, M., Cavaco-Paulo, A., Application of enzymes for textile fibres processing, Biocatal. Biotransfor. 26(5) (2008) 332 doi: http://dx.doi.org/10.1080/10242420802390457

32. Naika, G. S., Kaul, P., Prakash, V., Purification and characterization of a new endoglucanase from Aspergillus aculeatus, J. Agric. Food Chem. 55 (2007) 7566 doi: http://dx.doi.org/10.1021/jf070710p

33. Krishna, S. H., Sekhar, R. K. C., Suresh, B. J., Srirami, R. $D$., Studies on the production and application of cellulase from Trichoderma reesei QM-9414, Bioprocess Eng. 22 (2000) 467. doi: http://dx.doi.org/10.1007/s004490050760

34. Tavares, E. Q. P., Rubini, M. R., Sousa, T. M., Duarte, G. C. Faria, F. P., Filho, E. X. F., Kyaw, C. M., Silva-Pereira, I., Poças-Fonseca, M., an acidic thermostable recombinant Aspergillus nidulans endoglucanase is active towards distinct agriculture residues, Enzyme Res. 2013 (2013) 1. doi: http://dx.doi.org/10.1155/2013/287343

35. Akbarzadeh, A., Siadat, S. O. R., Motallebi, M., Zamani, M. R., Tashnizi, M. B., Moshtaghi, S., Characterization and high level expression of acidic endoglucanase in Pichia pastoris, Appl. Biochem. Biotechnol. 172 (2014) 2253. doi: http://dx.doi.org/10.1007/s12010-013-0672-6

36. Rawat, R. Kumar, S., Chadha, B. S., Kumar, D., Oberoi, H., $S$., An acidothermophilic functionally active novel GH12 family endoglucanase from Aspergillus niger $\mathrm{HO}$ : purification, characterization and molecular interaction studies, Antonie van Leeuwenhoek, 107 (2015) 103 doi: http://dx.doi.org/10.1007/s10482-014-0308-z

37. Maharan, A. K., Ray, P., Optimization and characterization of cold-active endoglucanase produced by Aspergillus terreus strain AKM-F3 grown on sugarcane bagasse, Turk J. Biol. 39 (2015) 175. doi: http://dx.doi.org/10.3906/biy-1408-22

38. Zhang, F., Zhang, X., Yin, Y., Li, W., Cloning, expression and characterization of a novel GH5 exo/endoglucanase of Thermobifida halotolerans YIM 90462T by genome mining. J. Biosci. Bioeng. 120 (2015) 644. doi: http://dx.doi.org/10.1016/j.jbiosc.2015.04.012
39. Bera-Maillet, C., Arthaud, L., Abad, P., Rosso, M., Biochemical characterization of MI-ENG1, a family 5 endoglucanase secreted by the root-knot nematode Meloidogyne incognita, Eur. J. Biochem. 267 (2000), 3255. doi: http://dx.doi.org/10.1046/j.1432-1327.2000.01356.x

40. Yin, L., Huang, P., Lin, H., Isolation of cellulase-producing bacteria and characterization of the cellulase from the isolated bacterium Cellulomonas Sp. YJ5, J. Agric. Food Chem. 58 (2010) 9833 doi: http://dx.doi.org/10.1021/jf1019104

41. Sinegani, S. A. A., Emtiazi, G., The relative effects of some elements on the DNS method in cellulase assay, J. Appl. Sci. Environ. Mgt. 10(3) (2006) 93. doi: http://dx.doi.org/10.4314/jasem.v10i3.17326

42. Deep, K., Poddar, A., Das, K. S., Cloning, overexpression, and characterization of halostable, solvent-tolerant novel $\beta$-endoglucanase from a marine bacterium Photobacterium panuliri LBS5T (DSM 27646T), Appl Biochem Biotechnol. 178 (2016) 695. doi: http:/dx.doi.org/10.1007/s12010-015-1903-9

43. Park, J., Park, K., Song, H., Shin, H., Saccharification and adsorption characteristics of modified cellulases with hydrophilic/hydrophobic copolymers, J. Biotechnol. 93 (2002) 203. doi: http://dx.doi.org/10.1016/S0168-1656(01)00379-0

44. Sun, Y., Cheng, J., Hydrolysis of lignocellulosic materials for ethanol production: A review, Bioresource Technol. 83 (2002) 1 . doi: http://dx.doi.org/10.1016/S0960-8524(01)00212-7

45. Chen, Y., Yang, C., Chang, M., Ciou, Y., Huang, Y., Foam properties and detergent abilities of the saponins from $\mathrm{Ca}-$ mellia oleifera, Int. J. Mol. Sci. 11 (2010) 4417. doi: http://dx.doi.org/10.3390/ijms11114417

46. Mizutani, C., Sethumadhavan, K., Howley, P., Bertoniere, $N$., Effect of a nonionic surfactant on Trichoderma cellulase treatments of regenerated cellulose and cotton yarns, Cellulose 9 (2002) 83. doi: http://dx.doi.org/10.1023/A:1015821815568

47. Eriksson, T., Borjesson, J., Tjerneld, F., Mechanism of surfactant effect in enzymatic hydrolysis of lignocellulose, Enzyme Microb. Technol. 6 (2002) 353. doi: http://dx.doi.org/10.1016/S0141-0229(02)00134-5

48. Lingxi, B., Danqing, Z., Jianxin, J., The effect of lignin and Sapindus saponin on enzymatic hydrolysis of cellobiose, Res. J. Biotechnol. 8(8) (2013) 49.

49. Feng, Y., Jiang, J., Zhu, L., Yue, L., Zhang, J., Han, S., Effects of tea saponin on glucan conversion and bonding behaviour of cellulolytic enzymes during enzymatic hydrolysis of corncob residue with high lignin content, Biotechnol. Biofuels 6 (2013) 161 doi: http://dx.doi.org/10.1186/1754-6834-6-161

50. Aydın, S., Yardımcı, Y. M., Mechanical properties of four timber species commonly used in Turkey, Turkish Journal of Engineering and Environmental Sciences 31 (2007) 19.

51. Laurinovica, L., Jasko, J., Skripsts, E., Dubrovskis, V., Biochemical methane potential of biologically and chemically pretreated sawdust and straw, Engineering for Rural Development 23 (2013) 468.

52. Zhao, X., Zhang, L., Liu, D., Comparative study on chemical pretreatment methods for improving enzymatic digestibility of crofton weed stem, Bioresour. Technol. 99 (2008) 3729

doi: http://dx.doi.org/10.1016/j.biortech.2007.07.016

53. Lin, F., Irfan, M., Nadeem, M., Syed, Q., Effect of $\mathrm{NaOH}$ and $\mathrm{H}_{2} \mathrm{O}_{2}$ on degradation of saw dust, Journal of Klagenfurt 20(1) (2013) 381 . 
54. Sukumaran, R. K, Singhania, R. R, Pandey, A., Microbial cellulases_production, applications and challenges, J. Sci. Ind. Res. 64 (2005) 832.

55. Montazer, M., Maryan, A. S., Application of Laccases with Cellulases on Denim for Clean Effluent and Repeatable Biowashing, J. Appl. Polym. Sci. 110 (2008) 3121. doi: http://dx.doi.org/10.1002/app.28920

56. Montazer, M., Maryan, A. S., Influences of Different Enzymatic Treatment on Denim Garment, Appl. Biochem. Biotechnol. 160 (2010) 2114. doi: http://dx.doi.org/10.1007/s12010-009-8727-4

57. Maryan, A. S., Montazer, M., A cleaner production of denim garment using one-step treatment with amylase/cellulase/laccase. J. Clean. Prod. 57 (2013) 320. doi: http://dx.doi.org/10.1016/j.jclepro.2013.05.041

58. Hurst, P. L., Nielsen, J., Sullivan, P. A., Shepherd, M. G., Purification and properties of a cellulase from Aspergillus niger, Biochem. J. 165 (1977) 33. doi: http://dx.doi.org/10.1042/bj1650033
59. Bakare, M. K., Adewale, I. O., Ajayi, A., Shonukan, O. O. Purification and characterization of cellulase from the wildtype and two improved mutants of Pseudomonas fluorescens, Afr. J. Biotechnol. 4(9) (2005) 898.

60. Romaniec, M. P. M., Fauth, U., Kobayashi, T., Huskisson, N. S., Patrick, J., Demain, A. L., Purification and characterization of a new endoglucanase from Clostridium thermocellum, Biochem. J. 283 (1992) 69. doi: http://dx.doi.org/10.1042/bj2830069

61. Pol, D., Laxman, R. S., Rao M., Purification and biochemical characterization of endoglucanase from Penicillium pinophilum MS 20, Indian J. Biochem. Bio. 49 (2012) 189.

62. Saha, B. C., Production, purification and properties of endoglucanase from a newly isolated strain of Mucor circinelloides, Process Biochem. 39 (2004) 1871. doi: http://dx.doi.org/10.1016/j.procbio.2003.09.013

63. Yan, H., Dai, Y., Zhang, Y., Yan, L., Liu, D., Purification and characterization of an endo-1,4- $\beta$-glucanase from Bacillus cereus, Afr. J. Biotechnol. 10(72) (2011) 16277. 